\title{
Green Auditing in the Anglican Church of Canada: To Finance or not to Finance
}

\author{
Daphne Rixon \\ Saint Mary's University \\ Judy Rois \\ Trinity College \\ University of Toronto \\ Anglican Foundation of Canada \\ Alex Faseruk \\ Memorial University
}

This paper analysis the results of the Anglican Church of Canada's (ACC) green audit project. For this research, we interviewed nine parishes who participated in the green audit initiative. Our research found that a more standardized process with standardized forms and feedback within specified timeframes should be considered before a new program is adopted. The study found that green auditing in its current form is of little use to the church in developing meaningful financial metrics to fully measure the efficacy of environmental auditing. Ultimately, the ACC must maximize the benefits to parishes, while being mindful of the costs.

\section{INTRODUCTION}

It is not unusual for the term 'auditing' be used in many different situations other than attesting to the accuracy of accounts and financial transactions, which was the initial paradigm under which public accounting took place. Social and environmental auditing can be employed in many different ways to mean many different things. Then there are subsets within the field of environmental auditing, such as green auditing, which is the focus of this paper in examining the rather recent,and quite frankly rather late, interest in green auditing for the Anglican Church of Canada (ACC). Unfortunately, its recent, and somewhat haphazard, introduction has meant that environmental auditing in its current form is of little use to the church in developing meaningful financial metrics to fully measure the efficacy of environmental auditing. The most salient issue then becomes whether or not subsequent green auditing projects be financed given the recent experience of the ACC. This paper is organized into six sections.

This first section serves as an introduction to the concept of environmental auditing with the emphasis on green auditing within the ACC. The second section introduces reasons why audits take place in environmental auditing, outlining the very basic and often highly rudimentary financial paradigms, which 
have been employed in measurement. The third section outlines the antecedent conditions in the ACC, while the fourth section provides the methodology used to interview the nine parishes that completed the initial pilot project in green auditing. The fifth section analyzes the questionnaire data in green auditing from this pilot project. The sixth section concludes the paper by providing both suggestions for future directions which the ACC could undertake.

\section{ENVIRONMENTAL AUDITING}

Although social accounting has existed in some form since the nineteenth century [see Guthrie and Parker (1989) for example], it was only in the early to mid-1970s that it gained attention in its current form and became popular as greenauditing. The ACC waited until 2010 before green auditing became a pressing issue and in reality is still only in the feasibility phase. Matthews (1997) postulated whether 25 years of social and environmental accounting research was a cause to celebrate. Now, more than two decades later, accountants still ponder the effectiveness of green accounting and auditing standards. From a financial perspective, the more interesting question is whether or not environmental auditing programs should be financed, especially those entities in the not-for-profit or charitable sectors where funds are extremely limited and returns might neither be readily observed nor measured.

Environmental audits are metrics and tools that organizations use to identify or define their full range of environmental impacts and assess the compliance of their activities to various laws and regulations, as well as with the requirements and/or expectations of their stakeholders. They also serve as a means to identify opportunities to reduce expenditures through cost cutting measures on an incremental cost basis or enhanced efficiency, improvements in work quality, enhanced employee health and safety, reductions in liabilities, and achievement of other forms of business value maximization through incremental revenue generation. (http://www.greenbiz.com/research/report/2003/02/12/green-auditing)

Companies and organizations conduct environmental audits of their operations for a variety of highly specified reasons which are not necessarily confined to the following: to demonstrate that organizations understand the various legal requirements; to ensure their environmental performance is compliant with applicable laws and regulations; to identify potential liabilities; to understand the environmental interactions of products, services and activities; to align environmental performance with their stated goals and strategy; to identify opportunities to reduce costs or increase revenue; to improve process and materials efficiency; and in response to stakeholder requests for increased disclosure.

Auditing environmental performance, especially aspects of performance not required by law, is a relatively new phenomenon. Few organizations conducted environmental audits a decade ago, and comprehensive audits that examine the full range of an organization's operations, including the impacts of creating and delivering its goods and services, the sourcing of its supplies and raw materials, the operations of its offices and other facilities, and its relationship with employees, suppliers, customers, and others. All these activities remain relatively rare, and, therefore, add a degree of difficulty in their measurement: hence, an understandable a reluctance to finance environmental or green audits.

Recently increased attention has been paid to auditing by companies, academic organizations, and governmental agencies. The recent growth of environmental auditing fits with a variety of business and social trends, including changing stakeholder expectations and a growing focus on the environmental impacts of the private sector. Conducting an audit usually requires outside expertise. The current marketplace offers services that carry varying levels of cost and expertise. Some involved in providing these services are not-for-profit assessment programs; large accounting firms; environmental services firms; and, independent auditors. (http://www.greenbiz.com/research/report/2003/02/12/green-auditing)

Environmental audits literally come in all shapes and sizes. Companies may conduct an audit to examine general practices, regulatory compliance, environmental management systems, communications, risk, energy use, and materials and other supply-side issues, as well as conduct audits that combine any or all these components. The size of an audit ranges from informal self-reporting on specific initiatives, using checklists, for example, to the utilization of independent third parties to conduct or verify 
comprehensive examinations that measure the full range of environmental impacts across a company's entire operations and activities.

The scope of an audit, and the methodologies used to uncover objective evidence, may include (http://www.greenbiz.com/research/report/2003/02/12/green-auditing):

- Measuring key environmental parameters

- Analyzing raw and test data

- Reviewing purchase orders and invoices

- Inspecting facilities

- Interviewing employees, managers, and executives

- Communicating with contractors, vendors, customers, and regulators

- Examining policies, internal records, reports, and public statements relating to the environment

- Comparing audit results to previous audits, as well as to industry standards and best practices

To identify some of the services offered by those faith-based organizations that foster religious-based services consider the Organization Faith \& the Common Good which has set as their target, Seeking a Common Ground for the Common Good through the services (http://greeningsacredspaces.net/what-wedo/promote-multi-faith-community-engagement/):

- Sacredness of Water

- Renewal Energy Revival

- Fossil Free Faith

- Neighborhood Extreme Weather Resilience

- Green Audit

- Mission per Square Foot

- Outdoor Greening-Sacred Greenspaces

- Forming a Green Team

- Steps to Greening

- Mapping the Network

- GSS (Greening Sacred Space) Certification

- Green Sacred.

In bringing the plan into action, one has to take into account the various organizational perspectives. Any audit should have top management's approval and resources, providing auditors (whether internal or external) the authority and means to conduct a thorough investigation. For all types of environmental audits, there are several generally acknowledged good practices for companies to follow as outlined in: (http://www.greenbiz.com/research/report/2003/02/12/green-auditing)

There are also a variety of strategies for the correct and implied usages of the results of audits. Some organizations keep results strictly for internal use, while others choose to publicize them widely.

- Bethlehem Steel maintains an environmental compliance index that tracks the number of incidents reported to or cited by government agencies relative to air pollution, water discharges, oil and chemical spills, and notices of violation. The company uses the index as a benchmark for continuous improvement in environmental performance.

- Ford Motor Co. released its first environmental and social impact report in 2000. Titled "Connecting With Society," the report assessed the company's environmental, social, and economic impacts. Ford followed the Global Reporting Initiative's guidelines.

- The Body Shop was recognized by the British nonprofit Sustainability for its comprehensive reporting on social and environmental impacts -- and the company's efforts to address these issues.

Benefits to an organization are: (http:/www.greenbiz.com/research/report/2003/02/12/green-auditing)

- Operating efficiencies

- Quality 
- Health and safety

- Liability protection

- Regulatory compliance

- Internal coordination

- Stakeholder communications

- Public image

- Strategic management

- Mission statements

- Time and other resources

- Confidentiality

The generally acknowledged good practices for companies to follow are outlined in:

(http://www.greenbiz.com/research/report/2003/02/12/green-auditing)

- Determine the scope

- Identify metrics and benchmarks

- Communicate the goals of the audit

- Establish a "no blame" policy

- Conduct the audit during normal operations

- Summarize the findings

- Verify the results

- Share the findings

- Repeat the process

\section{THE INITIAL EXPERIENCE OF THE ACC WITH GREEN AUDITING}

More often than not churches can be slow and reactive in adopting accounting, managerial, and financial practices as found by Rixon and Faseruk (2012, 2014), and Rixon, Rois and Faseruk (2014). In the arena of green auditing it was not until 2013 that the ACC undertook a financial program to fund green auditing. The ACC announced a maximum grant of $\$ 1,000$ (all quotations are in Canadian dollars), which was outlined in Ali Symons' article (April 13, 2013), "New grants help churches go green." The article announced that until May 31, Canadian Anglican congregations were able to apply for grants up to $\$ 1,000$ in order to subsidize a green building audit. The grant was intended to help local congregations to identify specific areas of their buildings that would benefit from becoming more energy efficient. This initiative is, of course, a highly limited scope for a so-called audit, and would only meet one of the criteria for the comprehensive audit outlined previously in this study. Grammatically, the use of green as a misplaced modifier could be problematic as most church buildings are not green. The article contends that some congregations had already conducted an analysis to determine the flaws in church buildings, such as to fix an old, inefficient furnace, a room with hot appliances and cooling systems close together, and a front door so drafty that the congregants call it the loonie [dollar] dispenser. Through investing in more energy efficient, cost-saving improvements, the church would be left with additional incremental cash flow to finance mission for mission. By reducing expenses the savings on operating expenses could be used to finance the intended strategy of the church. The ACC considers these audits as a step to live the fifth Mark of Mission, "to strive to safeguard the integrity, and sustain and renew the life of the earth."

In a more practical sense, the article goes on to describe the improvements as maximizing mission per square foot, which is a metric designed to demonstrate the efficiency of the green audit. The philosophy is to steward the space in the best possible way considering, heating, water use, cleaning products, and even whether pews are the best way to use nave and sanctuary space. Intangible benefits, which are difficult if not impossible to develop metrics, would be community-building (analogous to goodwill in a corporate setting) and internal or product champions or green teams within a congregation. While the application process and the audit itself are not time-consuming, it was considered imperative that parishes be committed to making change. In exchange for the grant, parishes were required to host a public 
information seminar on Greening Sacred Spaces on Energy Efficiency. The question arises whether or not the marginal benefits would exceed the marginal cost of the project.

In a capital budgeting paradigm, there should be a sufficient positive cash flow to meet the cost of the project to arrive at a positive NPV. And, of course, a usual concern in capital budgeting is how to measure the cost of capital for a project. The cost of capital measurement is difficult enough for publicly traded corporations, and its measurement would be greatly exacerbated given the not-forprofit and charitable status for churches.

The Green Building Audit grants are a result of resolution A180 on climate change, passed at the General Synod of the ACC in 2010. A General Synod is the ruling council of the ACC which meets on a triennial basis. In 2013, the adopted resolution encouraged the dioceses to do the same (Canada had the equivalent of 30 dioceses at that time spanning the country). Grants were provided by General Synod's Ministry Investment Fund, and the audits were conducted in cooperation with Greening Sacred Spaces, a project of the interfaith coalition Faith and the Common Good.

According to the ACC, the 2010 General Synod resolution A180 was one of the key ethical and religious challenges of the current time. Emissions from the burning of fossil fuels are pushing carbon dioxide concentration levels in the atmosphere which are higher than at any time in recorded history. In the 2010-2013 triennium, the Creation Matters Working Group (formerly named Greening Anglican Spaces) focused on engaging 40 parishes across Canada in a GREEN UP initiative of the Canada Green Building Council to have parishes gather and provide energy data to reduce energy use to free up resources for local mission. Internationally, Anglican bishops from around the world called on the Church to fast for the climate on the first of every month. For 2013, the Ministry Investment Fund indicated that it would provide $\$ 15,000$ to support further work with the Canadian parish-greening efforts. These initiatives are best understood as a pilot project given that there were more than 1,600 parishes at that time. Not only was there concern with the level of carbon emissions at that time, but other environmental issues pertaining to the exploration, extraction, shipment and refining of hydrocarbons could also prove to be problematic, such as, the BP spill in the Gulf of Mexico in 2010, fracking across many jurisdictions, the Keystone Pipeline debate on whether to ship Alberta crude oil (perceived as dirty oil) across the continental US to be refined in Oklahoma or Texas and transshipped elsewhere, and Lac-Mégantic rail disaster when 74 car loads of crude oil derailed in 2013, the worst rail disaster in Canadian industry.

At that time public opinion hardened against both the incumbent Conservative government and oil companies. The Conservative government lost the election. Neither the Obama nor the Trump administration were able to gain approval for the Keystone pipeline. In 2018, the Liberal government, under Prime Minister Trudeau, bought the Trans Mountain Pipeline from Kinder Morgan when the company refused to invest further, given the increased uncertainty of the project following court challenges and jurisdictional squabbling between provincial governments and the federal government. Kinder Morgan effectively used abandonment value to walk away from the project and, in fact, used an implied put option to sell the project to the federal government. Alternatively, the federal government used an implied call option to affect the purchasing of the pipeline. Whether or not the call option had a positive intrinsic value is still to be seen. The uncertainty surrounding oil prices and its impact on green auditing has already been felt in many areas, reflecting risk assessment in environmental areas.

In order to promote this green auditing initiative within the ACC, a video was produced, available online, that featured the Primate (presiding Archbishop) of the ACC who identified climate change as a moral and spiritual challenge that demands a response from Canadian Anglicans. There were also links to a carbon calculator to instruct people to be more conscientious about the ecological footprint and to solicit charitable donations for greening activities in the ACC. A manual was produced for use within churches, which centered on five themes: climate change, eco-justice, water, creation and redemption, and biodiversity. Each section included sermon notes, collects (opening prayers) for the day and liturgical material. Lastly, Sunday School material was also produced. All these goals were to be achieved for the parish to receive $\$ 1,000$ in seed money, which implies this upfront money is the initial investment in a capital budgeting exercise. 
One example of Sunday School material that was provided was for Sunday School teachers focused around Earth Day (April 22nd) each year. Sunday School teachers were asked:

- Do you use white or chalk boards instead of writing on newsprint?

- Do you use rubber stamps and inkpads instead of stickers?

- When doing arts and crafts do you encourage (and model) using the least amount of a product to complete the task

- Use recycled materials wherever possible?

- Avoid using food products?

- Do age groups share resources, so fewer supplies need to be bought and they can be used up before they become unusable?

- Whenever possible do you choose activities that use recycled materials, or no materials at all?

- Do you have recycle bins in your learning area?

- Do you have a checklist to remind you to do things like turn off the lights, turn thermostats down etc. each week?

- Do you use environmentally friendly cleaning supplies to clean furniture and toys?

- Do you use supplies made from recycled materials?

- Do you use washable cups and plates instead of disposable?

- Do you use energy saving light bulbs?

- Do you use curriculum that can be downloaded, so that you only print what you need?

- When printing session outlines, do you print on both sides of the paper?

In 2013, nine Anglican parishes across Canada conducted a Greening Sacred Spaces Green Audit, which were facilitated and paid in part by the ACC. All nine audits were completed between October 22 December 2, 2013, (seven in Ontario, one in Quebec, one in Nova Scotia). Participating ACC parishes committed to the following (Green Audits 2014):

a. Pay one-third of the cost of the audit.

b. Proving the previous year's data to the GSS on parish energy consumption, gas, electricity, water, etc, with both the dollar figures and the consumption figures (m3, $\mathrm{kWh}, \mathrm{L}$, etc).

c. Summarizing the parish's response to the Green Audit findings to help document energy saving actions and achievements. Summaries are due approximately 36 months following the audit, after the parish has had time to implement Green Audit recommendations.

d. Hosting a public information seminar with GSS on energy efficiency. This should take place within a year of the audit date, at a time mutually convenient to the parish and GSS.

e. Collecting energy consumption data for at least two consecutive years following the audit. This data will help establish a baseline against which parishes can measure environmental performance improvements year over year.

In 2014, the Faith and Common Good/Greening Sacred Spaces provided a yearend report in which they provided limited subjective evidence which contended that for the most part the initial phase of the audits were considered to be relatively successful. The report also provided some insight to the parishes performing Green Audits with suggestions listed for improvement. Yet, on the same token, the full effect has to be observed as there was a three year phase in period. Although 40 parishes were targeted, only nine completed the audits with less than the maximum allocated of the $\$ 15,000$ being taken up. Note that parish pastors leave, new ones come, and volunteer parish councils are elected on a year-by-year or biennial basis. Corporate governance issues pertaining to multi-year funding projects in the ACC and organizational memory can be problematic for realizing the benefits of the program.

There are also issues whether or not there is buy-in for the program at the parochial level, or whether parishes want to commit either the time or resources to conduct a green audit. If there is only high level support for the program, it might not be successful in the longer term and maybe the plan will not be repeated. The application for funding aptly referred to as Anglican Church of Canada Green Audit Program Application Form outlined the information required before making a decision. It must be noted that many clergy were opposed to filling out yet another form or participating in yet another survey. There 
have been expressions of support by many other ecumenical partners, such as The Episcopal Church (the branch of the Anglican Communion in the United States) and the Evangelical Lutheran Church of Canada, and on Good Friday 2015 the declaration The World is Our Host: A Call to Urgent Action for Climate Justice was made by 17 Anglican Bishops from the six continents, as well as joint declarations with KAIROS, an ecumenical think-tank and action group.

\section{METHODOLOGY}

Building on the previous section, which outlined the early experiences of the green auditing program of the ACC, this paper provides a case study of the limited metrics, financial or otherwise, used to evaluate the green audit exploratory program adopted by the ACC through its General Synods in 2010 and 2013. This paper analyzes the questionnaire administered to parishes involved in the initial program and discusses the findings of the interviews by participating parishes. Then, in the concluding section, comments are made whether the program should be replicated, expanded or abandoned.

Over the period August to November 2018, the authors conducted interviews (either onsite or over the phone) via an opened ended questionnaire or visited websites with all parishes that took part in the green audit. Given the open ended nature of the interviews, there was a great deal of anecdotal evidence that was provided. In some cases the respondents worked from aide memoire notes, while others had spreadsheets showing data before and after the audit. In some interviews some respondents noted that they did not have the data necessary to support their observations, while others would say that there were several other new and concurrent activities were undertaken by the parishes, such that although the audit may have resulted in savings, the other activities would add additional demands on power. So, it was not always easy to measure the simple effect of before and after the audit. In certain instances, more than one respondent took part in the interview. The data were then compared across the various respondents and also compared to the summary of the Green Audits yearend 2014. The authors very quickly noted that there were differences between parishes which arose due to the varying amount of buy in from various individuals, be it driven by either a product champion of a committee (maybe cadre would be a better term) of individuals.

\section{INTERPRETATION OF RESULTS}

The ACC and Greening Sacred Spaces in their document Green Audits 2014 commented on the process that had been undertaken. They contend that there was generally a sense of satisfaction and appreciation for the green audit experience. They observed that even those who felt that they knew what actions were needed prior to the audit were surprised by the range of actions which can be undertaken. The congregations felt that having the information packaged in concrete ways, such as a "to-do list," benefited their parishes (Green Audits 2014, p. 17). Where the current study found commonality with these initial observations, the questionnaire, site visits, phone conversations, and examination of websites all provided additional insight into how successful the program was from a financial sense. As a consequence, constructive critical feedback is provided to suggest how this pilot program can be improved in the future and whether or not this program ought to be financed by the ACC.

Refer to Appendix A for the 12 interview questions that were administered. In the first question, the respondents were asked how the parish decided to participate in the green audit program. While this program was advertised by the ACC and many dioceses, only three of the respondents indicated that notification by the dioceses were paramount in having them pursue the program. The grassroots formation within a parish by local product champions or an existing environmental committee were much more prevalent in becoming involved in the program with five congregations indicating that a few dedicated individuals usually drove the process. In the subsequent questions, the more successful participants in the green audit program came from this grass roots initiation of the program. One congregation noted that they applied for a grant from a funding agency external to the ACC and in order to receive that grant they needed an environmental assessment completed. The external funding agency agreed to accept the green

Journal of Accounting and Finance Vol. 19(4) 2019219 
audit as the environmental assessment, which meant that particular congregation was able to leverage their funding to receive an additional incremental infusion to be spent on projects other than those outlined in the green audit.

The second question dealt with who was responsible for coordinating the audit and responding to the recommendations, with supplemental question whether or not a committee was formed. All respondents reported that there was a lead person who assumed responsibility for seeing that the audit was carried out and that this person(s) would receive the recommendations from the audit. In only three of the cases were the results communicated to a committee. While only one standing committee was formed, the results were communicated to an ad hoc committee that would exist for the duration of the program. In the last case the results were delivered to an existing committee. In one case, the parish auditor/treasurer became involved and the committee grew to 17 people who were most interested in further the process. In six cases, committees were not formed, but relied on alternative arrangements usually under the lead of a product champion who either formed informal groups or co-opted lead parishioners as required. In two instances it was simply a group of one. From an heuristic viewpoint, congregations generally face problems in staffing not only committees, but also elected offices within the church's governance structure, such as wardens, executive members (treasurer, secretary), and members of parish councils. Accordingly, it would be difficult in many parishes to staff an additional committee, as committee fatigue would undoubtedly go hand-in-hand with donor fatigue that parishes are experiencing in the face of dwindling congregations owing to shifting demographics in an ageing population.

In the third question, respondents were asked if the parish had any difficulty in providing the required data and if so to describe the difficulty. In all instances the parishes responded that they were able to provide the data about consumption of electricity, gas and water. While all parishes could provide the data, a complaint that was voiced by three parishes was that it was time-consuming to generate. The other six parishes indicated that the treasurer had the data readily available on a computerized database, usually a spreadsheet. All the congregations are responsible for providing financial statements to the congregation and the diocese, and, as such, must go through a review or audit of these statements. Consequently, these data should be readily accessible by the treasurer. However, given the disparate state of maintaining financial records, some parishes would have greater sophistication in generation of their financial records, their usage and interpretation. Other databases in the parish can also be time-consuming and problematic, such as the maintaining of the actual congregants who are on the parish rolls and a database of the donors to the congregation, including how much and when. In widely held public corporations obtaining a list of the shareholders is still a time consuming exercise. One congregation noted that nothing was done with the data once generated feeling that it was a time-consuming exercise which generated few benefits for the congregation following its completion. This last concern leads into the fourth question, the degree of agreement that a parish had with the green audit.

Of the nine respondents, eight agreed strongly with the recommendations, although there were a few caveats noted. One parish was unable to find the actual recommendations, but felt that while the process was remembered as being good, they were unable to comment on specific items within the actual audit. Some of the usual items contained in the green audit that would result in cost savings from operating expenditures were switching to LED (light-emitting diode) bulbs (220 bulbs in one parish and 127 in another) in four parishes (although one did voice complaints about LED bulbs being too bright), using more insulation, installing of weather stripping, purchasing of new windows or doors, transitioning to low flow toilets/low pressure faucets, lessening use of environmentally unfriendly cleaning agents, recycle excess paint, turning off pilot lights on gas stoves, purchasing heat pumps and hot water heaters, and purchasing more fuel efficient furnaces were all agreed to be very important in implementing green auditing in the church building. In some incidents, there were government or utility programs that would provide subsidies for the acquisition of assets, e.g. LED bulbs.

The respondents also commented that there were unanticipated benefits. For example, in one parish, the green audit team advised the parish to leave ceiling fans on all the time and not to switch them off when the building was not being used for worship. The congregation believed prior to the recommendation that turning the fans off would save money and be more energy efficient. However, it 
was demonstrated that the movement of air was necessary to prevent the buildup of mold in the building and prevent rot from setting into the wooden structure. As well, the stagnant air would need to be rewarmed in the winter or re- cooled in the summer after the fans were turned back on. There was also a change in the culture of the congregation which made it easier to attract a younger demographic in one congregation, which was then able to institute a recycling program, as well as apply for grants from either the provincial or federal government, or in one case both.

Not all of the recommendations of the green audit were adopted by the parishes. In some cases, the recommendations were not implemented owing to lack of funds. While many of the operating decisions were implemented to result in lower marginal costs, some expenditures in capital budgeting were not, which would include extensive renovations and the installation of solar panels. Interestingly, another congregation that installed solar panels found it so lucrative that they considered selling their excess power feeling that the return on investment of the panels would start to be realized in a three to four year horizon, but this was the exception and not the norm. In another parish, the investor-owned utility that serviced electrical power for the area was reluctant to assist them in installing solar panels. Another congregation was concerned that extensive plumbing changes were required which would negate any cost savings that would come from the reduction of hot water charges. Incremental cost and revenue changes often have to be compared to capital costs as they would in any capital budgeting exercise.

Some recommendations were not adopted by one parish, as they felt that it did not fit the green audit program. For example, they were concerned about switching to gluten free wafers as the norm for the host used in Holy Communion, since very few people request a gluten free wafer, but felt that they could accommodate those desiring this option with a small stock of these wafers. They also rejected the use of locally sourced wines in Holy Communion feeling that it lacked the quality of the wine that they were already using and balked at using organic fair trade coffee. Another congregation felt that they could not switch from Styrofoam cups as they felt that these were part of their congregational culture.

Overall, the results of the audit were extensive, and many were readily adopted for financial reasons. Mostly, the respondents felt that incremental operating costs would be reduced and in some cases that incremental operating revenues would be enhanced, or greater access would be available or with the attraction of new environmentally conscious congregants, donations would increase. In some cases, the rejection of some recommendations was a result of the congregation feeling that the incremental decreases in costs or the incremental increase in revenue would not be sufficient to justify the capital expenditure. While this approach is, of course, the application of the NPV rule in capital budgeting, it should be noted that capital budgeting analyses were not conducted by the congregations. However, within the paradigm of behavioral finance, mental accounting appears to have been utilized.

In the fifth question, respondents were asked about how the committee and the contact person encouraged the congregation to become involved in the process with a supplemental question to describe the nature of the involvement. As most congregations did not form committees, the inclusion of other congregants into the process was varied and haphazard beyond the initial contact person or product champion. Having said that, there were a few success stories of additional integration of interested people. One respondent said that other individuals would be chosen strategically as many people would lack either the time, resources or competency to become involved at a higher extent. In most cases, congregants were encouraged to turn off lights or become involved in recycling or composting. Congregants were asked to refrain from trying to use the reprogrammable thermostats as too many changes by uninformed congregants negated the benefits of having this type of thermostat. Other congregations tried sign up lists, but these were of limited use in attracting people. Some parishes were in the midst of extensive renovations or capital campaigns and lacked the time to become involved in green initiatives. Moreover, the demographics of congregations were often to the detriment of involvement. One respondent discussed anecdotally how older congregants lacked the desire to become involved, whereas middle aged congregants were busy in other activities, both within and outside the church. Surprisingly, youth were not dedicated to the green initiative but were becoming involved in aspects of social justice.

There were several success stories. Two parishes reported extended recycling efforts. In one parish, after the annual general meeting, the parish noted an increase in green gardening, providing shelter for 
animals, and landscaping activities involving several hundreds of thousands of dollars. The respondent commented that it is much easier to raise funds for capital than the ministry of the church. This comment refers to capital rationing being undertaken in the church. Parishes do not have an unlimited supply of funds and face dwindling numbers of congregants, which means that problems of scarce resources must be addressed in any strategic plan.

The sixth question, which forms the raison d'etre for the green audit, is to describe the environmental impact of the implementation of the audit recommendations and to state how it, the environmental impact, was measured. Given that the cost data for green audit was successfully generated for all the congregations, the analysis, from a prima facie viewpoint, should be quite easy to generate as one should do a comparison before the audit and then after the recommendations were implemented, usually in year one but up to three years following the implementation. In the most sophisticated analysis, the respondent indicated comparing the cost of the installation of solar panels to the cost savings that were made in order to calculate a payback period. One congregation used graphs/charts of various financial metrics to demonstrate visually what their savings were.

Another congregation did the analysis on a year over year and a month over month basis to incorporate seasonality into their analysis, which successfully generated data to demonstrate incremental savings on a seasonal basis. Given the limited timeframe, they lacked a time series database to demonstrate seasonally adjusted figures from a time series analysis. Given the limited timeframe of the green audit program, only a limited cross sectional analysis can be undertaken and not a longitudinal study. One congregation quoted that costs decreased from $30-40 \%$ but did not have data to support this figure. It was also worthy of note that intangibles, which by their very nature are difficult, if not impossible to address, could also increase. Parishes suggested that there were more positive feelings in the parishes following the green audit. In one instance the number and quality of flowers on the church property increased. The congregation prides itself on its flowers. But, the question remains how the increase in flowers could be factored into the value of a parish. On the unsupportive side, one congregation said that they lacked a sufficient database to undertake the analysis, while another simply stated that it had not yet been done.

The seventh question asked respondents to state the financial impact of the green audit recommendations. Measuring the financial impact of the green audit and the improvements, due to implementation of the green audit recommendations, are difficult to fully measure. When the usual financial tools would be a before and after analysis coupled with the "with-without" principle, there are several mitigating factors that need to be examined. Five of nine respondents used utility bills to ascertain the dollar amount of the savings. One congregation reported the savings being in the vicinity of 30-40\%. Two others in eyeballing the data said that it was a cost savings, while a third congregation ran their fingers down a comparative spreadsheet. Some problems in determining the actual dollar savings were that new programs were introduced, such as drop-in centers being established, additional congregational meals, allowing outside groups to use the church, and additional expenses that would be incurred due to expanded infrastructure. One congregation provided an extensive report for the AGM.

The eighth question asked respondents how the results of the audit were communicated to the parishioners. All the congregations conveyed the results of the green audit in the usual ways open to the church, such as, by church bulletins (distributed on Sunday mornings), church magazines/newssheets (distributed on a monthly basis, either in hard copy or by email), reported to parish council or its various committees, e.g. building committee, or by multiple means. Interestingly, the respondents did not extensively report posting the results on a webpage or by using social media, such as Facebook. In churches, more often than not, the webpage is out of date, as parishes tend to have volunteer webmasters. Facebook pages tend to be quickly updated, but more pressing issues and newsworthy items are posted before rather mundane items like green auditing. One parish reported that no parish organizations had been informed about the recommendations surrounding the green audit.

Given that the green audit recommendations were to be monitored over a three year period following the audit, respondents were asked in the ninth question about the ways that parish interest and momentum were maintained in that period. In seven cases, the congregations reported lack of excitement surrounding 
the green audit. As reported in the previous paragraph, green auditing is largely a mundane issue that does not receive a great deal of attention and while excitement was reported in some parishes during the first year, the excitement dissipated subsequent to that initial year's excitement, with reasons cited either that the audit was helpful, but not overpowering or that the parish planned on doing it anyway. The green audit was viewed as simply being the catalyst without providing long term benefits. Accordingly, the program was not unlike a current assets management decision, wherein the asset was self-liquidating and quickly ran its course without any residual interest being witnessed. In one other case, the results of the green audit have not been shared with the congregation. Understandably, no momentum or interest were established.

The one notable exception where there was continued interest was in the case when a parish received a bequest for the greening of the parish. The bequest was a donation wherein the proceeds would be spent on green projects over a number of years. The congregation, therefore, had a pool of money which they could not spend. So, the decision became more of a capital budgeting exercise and, from the tenets of behavioral finance, the presence of spendable funds enhanced the interest of the parish and maintained the momentum of the green audit, not only beyond the initial year, but also into the formative three year anticipated life of the project. However, on balance the idea of a three year timeframe and desire to maintain interest long- term is a highly questionable goal of the exercise.

The tenth question asked respondents to state, with reasons, whether or not the parish would be willing to continue with the green audit program. In seven of the nine cases there was no desire to continue in the green audit program. The major reason given was that all the benefits were already received and that there would be little benefit by redoing or staying in the program. The two dissenting viewpoints were first that there would be the desire to improve upon previous results and the second that circumstances change with the parish wanting to remain on top of the results, as variables change over time, such as the climate, legal requirements, and technology. From a finance perspective, the first reason is the same as the desire to reinvest, as a way of enhancing the value of the project by expending the funds to gain long-term benefits. In the second case, this environmental scan is a risk reduction strategy, which can aid parishes in achieving long run financial viability.

Given that parishes exist in the community, congregations were asked in the penultimate question if they hosted a public seminar on the greening of sacred spaces and to comment whether or not nonparishioners attended. In seven of the nine cases, no public meetings were conducted. In two instances where they were, they proved to be somewhat successful. In the first instance, a barbecue for the community was conducted along with an open doors attitude. In the second case, 30 people from the community attended an open meeting which had a very positive feeling. As no feedback was conducted on these sessions, it is unknown whether the meetings had any residual effect. Given that parishes were reluctant to have community-based meetings and that little information was gained from those who did hold them, it is debatable whether community meetings should be part of a revised green audit plan.

In the concluding question to the survey, respondents were asked if the ACC provided sufficient financial support for the green audit program. In all cases the respondents felt that the funds provided by the ACC were sufficient with two reporting that without this infusion the green audit would not have taken place. One parish reported that they also received funds from the diocese in addition to the ACC. One other parish commented that the attitude of the General Synod of the ACC to encourage the church to go carbon free was instrumental in participating in this program. However, one must be mindful that only a small number of parishes took the funding and that the program could have funded more parishes in this pilot program. Nonetheless, several salient points about the program are gleaned from the data to consider whether or not the ACC should continue to fund the green audit program or a go forth basis. 


\section{CONCLUSIONS}

Environmental audits can be a highly valuable tool for organizations in a wide range of sectors to improve their environmental and economic performance and reputation while reducing regulatory burdens, liabilities, and operating costs. Companies and organizations that are among the early movers in taking proactive environmental measures often are those that set the regulatory or stakeholder standards against which their colleagues and competitors are judged. However, to date environmental auditing has not yet proven to be effective in the programs of the ACC.

The Green Audits 2014 made several observations following their own analysis. First, they noted that there was an expectation across parishes that actions would be completed within the timeframe suggested by the program, but many parishes noted that they needed more time and financial resources to implement the recommendations. Second, all parishes requested extension beyond the April 2014, which was deemed to be unrealistic. Third, some parishes suggested that the audit process include a five-year evaluation tool following the initial report, a tool parish councils can use to extend the importance of the audit and its recommendations. Fourth, urban, suburban, and rural differences were noted. Specifically, in the rural environment, resources (cash, time, talent, labor, etc.) were difficult to acquire. While the suggestions were considered valuable and important to the future health of the parish and its buildings, the suggestions were difficult to implement.

In turning to the analysis of this questionnaire, the decision of whether or not to replicate the green audit program or to finance in another form suggests that a streamlining of the steps of the process and more effective targeting of potential parishes would result in better outcomes of the process. Environmentalism is at the forefront in the media and is at the heart of many church activities. Two examples of the various movements which readily come to mind are: 1 . to recognize creation as a season within the church,9 and: 2 . the church in an attempt to become greener has recently taken a stand against the indiscriminate use of plastics.10 Accordingly, environmental issues will not simply go away. Green auditing programs are a useful wayof ensuring that environmental issues continue to be at the forefront and are addressed. However, a more standardized process with standardized forms and feedback within specified timeframes should be considered before a new program is adopted.

The first issue deals with how parishes are identified or selected to take part in an environmental audit is important. With more than 1,600 parishes in Canada, only 40 were asked to take part in the pilot study and only nine completed the process, which meant that budgeted funds were not used. On a go forward basis, a better identification of parishes could result in a higher acceptance rate. While the majority of participating parishes were done through grassroots identification with product champions, it might be better to have parishes identified through the dioceses/spiritual areas across the country which could be done in conjunction with the Public Witness for Social and Ecological Justice Committee, a committee of the national ACC.

It also appears that committees were not usually formed at the parish level. So the requirement for a committee might not be appropriate in all circumstances. Instead one contact person and the parish treasurer, both of whom can then co-opt individuals as needed. might be more expedient in ensuring a successful green audit. Given the financial data requirements of the green audit, the parish treasurer seems the most appropriate person for generation of these data.

While parishes generally did not have any great difficulty in generating the data, there were concerns expressed over how to measure the benefits of the green audit. Accordingly, there should be a before and after form for the audit, which lists certain items such as electrical usage and its cost leading up to the implementation of the recommendations. Then, answer the question how did the consumption of electricity change following the recommendation, both in terms of units used and the cost. Parishes could be provided with a form that can easily be filled out listing these various amounts. The cost per unit is important as these costs can vary over time and the impact of inflation can be seen through an analysis of both consumption rates and cost per unit.

The data should also be analyzed on a monthly basis in order to capture the effects of seasonality. The best data that can be generated would be incremental costs and benefits, as the implementation of the 
audit is analogous to the capital budgeting decision. In addition, it would also be important to have the form indicate when new or additional programs were instituted by the parish. For example, having an additional parish meal for seniors on a weekly basis would result in an increase in electrical consumption, but the implementation of the audit's recommendations would conceivably have led to a reduction. By keeping track of new programs one can also view spikes in the data. Again, incremental data would be the most appropriate.

In the implementation phase, it might be necessary to expand the group for the actual implementation of the recommendations. For example, the recommendations might be carried out by a property committee, the ACW (Anglican Church Women) or the Sunday School teachers. While the notification of the green audit and its results was accomplished through several venues, it might be better to also have more frequent posting on websites and social media, such as Facebook. In investments and corporate governance, the tenet is to move towards full, continuous and timely disclosure of programs, which will be greatly enhanced through social media.

There should also be attention paid to the externalities which were generated but not necessarily anticipated nor measured. For example, parishes noted a change in attitude to the parish and its programs which probably meant that other initiatives were started and these were not anticipated in the initial audit. In capital budgeting, subjective externalities are difficult to initially measure, but these may eventually become quantifiable. It could be measured through an increase in using the parish's cash recycling program or increased usage of the parish's blue/green box program.

While it is of paramount importance to have buy in from the parish and to maintain the full, continuous and timely disclosure mentioned earlier, it is debatable whether or not the wider community is to be involved. In seven of the nine cases, there were no meetings held, which does not to have appeared affected the green auditing program. Moreover, in the one case which actualnumbers were provided, 30 individua ls attended the meeting, but none externalto the parish. Keeping the momentum going may well be a laudable goal, but the data suggest that after the initial period interest waned. This situation is not necessarily bad if greening becomes partof the psyche of the parish and people do all these undertakings as a matter of course. The initial investment of $\$ 1,000$ seems sufficient. It may pay future dividends. For the program to be replicated and become a success more attention needs to be paid to having a standardized program so that appropriate financial metrics are generatedand used to make appropriate decisions to maximize the benefits to the parish and the ACC, while being mindful of the costs. 


\section{REFERENCES}

Abdul-Rahman, A., \& Goddard, A. (1998). An Interpretive Inquiry of Accounting Practices of Religious Organisations. Financial Accountability and Management, 14(3), 183-201.

Armacost, R., \& Schneider, W. (1989). Financial Management in Church Operations. The CPA Journal, $59(4), 36-41$.

Arndt, T., \& McCabe, J. (1986). Communicating the Financial Aspects of Church Operations. The Ohio CP Journal, Spring, 25-29.

Azzone, G., \& Bertele, U. (1994). Exploiting green strategies for competitive advantage. Long Range Planning, 27(6), 69-81.

Bennett, R. (1991). How is management research carried out? In Smith, C. and P. Dainty (Eds). The Management Research Handbook. Routledge: New York, 85-103.

Blaza, A.J. (1992). Environmental management in practice", in Owen, D.L. (Ed.), Green Reporting: Accountancy and the Challenge of the Nineties, Chapman and Hall, London, 201-14.

Booth, P. (1993). Accounting in Churches: A Research Framework and Agenda. Accounting, Auditing and Accountability, 6(4), 37-67.

Boyce, L. (1984). Accounting for Churches. Journal of Accountancy, February, 96-102.

Brady, J., Ebbage, A., \& Lunn, R. (Eds.) (2011). Environmental Management in Organizations: The IEMA Handbook, 2nd edition. London, Earthscan.

Edwards, R. (1990). Financial Accountability in Religious Organizations. The National Public Accountant, 35(6), 16 - 18.

Elkington, J. (1990). The Environmental Audit: A Green Filter for Company Policies, Plants, Processes, and Products. Worldwide Fund for Nature, London.

Elkington, J., \& Jennings, V. (1991). The rise of the environmental audit. Integrated Environmental Management, 1(1), 8-10.

Ellis, L. (1974). Internal Control for Churches and Community Organizations. The CPA Journal, May, 45-48.

Geddes, M. (1990). The social audit movement”, in Owen, D.L. (Ed.), Green Reporting: Accountancy and the Challenge of the Nineties. Chapman and Hall, London, 215-41.

General Synod Communications. (2015, May 19). Subsidized Green Building Audits available for parishes. Retrieved from https://www.anglican.ca/news/subsidized-green-building-auditsavailable-for-parishes/30010763/

Gray, R.H., \& D. Collison (1991). The environmental audit: green-gauge or whitewash. Managerial Auditing Journal, 6(5), 17-25.

Green Audit. (n.d.). What is Green Audit? Retrieved from https://www.greenaudit.org/about/ Green Auditing. Retrieved December 2003, from https://www.greenbiz.com/research/report/2003/02/12/green-auditing

Guthrie, J., \& L.D. Parker (1989). Corporate Social Reporting: a rebuttal of legitimacy theory. Accounting and Business Research, 9(76), 343-352.

Hair, J. (2013, October 25). Anglicans speak on greening, transforming faith spaces. The Anglican Church of Canada. Retrieved from https://www.anglican.ca/news/anglicans-speak-on-greeningtransforming-faith-spaces/3006790/

Harding, S. (2013, April 17). Greening Your Sunday School. The Community. Retrieved from $\mathrm{http}$ //thecommunity.anglican.ca/children/6463/greening-your-sunday-school/

Hardy, L., \& Ballis, H. (2005). Does one size fit all? The sacred and secular divide revised with insights from Niebuhr's typology of social action. Accounting, Auditing and Accountability, 18(2), 238254.

Harper, B., \& Harper, P. (1988). Religious Reporting: Is It the Gospel Truth? Management Accounting (US), February, 34-39.

Irvine, H. (2005). Balancing money and mission in a local church budget. Accounting, Auditing and Accountability, 18(2), 211-237. 
Jacobs, K. (2005). The sacred and the secular: examining the role of accounting in the religious context. Accounting, Auditing and Accountability, 18(2), 189-210.

Laughlin, R. (1988). Accounting in its Social Context: An analysis of the Accounting Systems of the Church of England. Accounting, Auditing and Accountability, 1(2), 19-42.

Laughlin, R. (1990). A Model of Financial Accountability and the Church of England. Financial Accountability and Management, 6(2), 93-115.

Mathews, M.R. (1997). Twenty-five years of social and environmental accounting research. Accounting, Auditing and Accountability Journal, 10(4), 481 - 531.

Owen, D. (2008). Chronicles of wasted time: A personal reflection on the current state of, and future prospects for social and environmental accounting research. Accounting, Auditing and Accountability Journal, 21(2), 240-267.

Partners in Mission and EcoJustice Committee Report to General Synod. (2010). Retrieved from http://jointassembly.ca/wp-content/uploads/013-Partners-in-Mission-and-EcoJusticeCommittee.pdf

Rixon, D., \& Faseruk, A. (2012). Secular Tools and Sacred Goals, A Case Study of How Anglican Priests Are Embracing Management Accounting and Strategic Planning. Journal of Business Diversity, 12(1), 19-32.

Rixon, D., Rois, J., \& Faseruk, A. (2014). The Seven Deadly Sins of Church Accounting. Journal of Business Diversity, 14(1), 9-17.

Rixon, D., \& Faseruk, A. (2014). Not-for-Profit Accounting Standards: Should Churches and Private Enterprise Sing from the Same Hymnbook? Journal of Leadership, Accountability and Ethics,11(2), 134-147.

Rixon, D., \& Faseruk, A. (2018). Interviews with participating parishes. Summer and Fall 2018. Rowe, T., \& Giroux, G. (1986). Diocesan Financial Disclosure: A Quality Assessment. Journal of Accounting and Public Policy, (Spring), 57-74.

Stock, S. (1995). Church Reporting Made Easy. Management Accounting, 76(9), 56-59.

Strategic Sustainability Consulting. (n.d.). The SSC Green Audit. Retrieved from http://www.sustainabilityconsulting.com/greenaudit/

Symons, A. (2013, April 10). New grants help churches go green. The Anglican Church of Canada. Retrieved from https://www.anglican.ca/news/new-grants-help-churches-go-green/3006766/

The Anglican Church of Canada. (n.d.). About the Marks of Mission. Retrieved from https://www.anglican.ca/marks/about/

The Anglican Church of Canada. (n.d.). Resource Category: Ecological Living. Retrieved from https://www.anglican.ca/resource-category/ecological-living/

The Anglican Church of Canada. (n.d.). Season of Creation. Retrieved from https://www.anglican.ca/publicwitness/season-of-creation/

The Church of England. (n.d.). Lent Plastic Challenge. Retrieved from http://exeter.anglican.org/wpcontent/uploads/2018/02/Plastic_Free_Lent.pdf 


\section{APPENDIX A}

\section{GREEN AUDITING IN THE ANGLICAN CHURCH OF CANADA}

1. Tell me about how your parish decided to participate in the Green Audit program?

2. Who was responsible for coordinating the audit and responding to the recommendations? Did you form a Committee?

3. Did you have any difficulty in providing the required data? If so, describe.

4. Did you agree with the audit recommendations? If not, explain.

5. Did you and your committee encourage the parish congregation to get involved? If so, please describe the nature their involvement?

6. What was the environmental impact of the implementation of the audit recommendations? And how was this measured?

7. What was the financial impact of the implementation of the green audit recommendations?

8. How were the results of the audit and recommendations communicated to the parishioners?

9. How did you keep up parish interest and momentum in the implementation of the Green Audit recommendations over the three-year period subsequent to the audit?

10. Would you be willing to continue with the Green Audit program? Why or why not?

11. Did you host a public seminar on Greening Sacred Spaces? Did non-parishioners attend?

12. Did the ACC provide sufficient financial support for the Green Audit program? Explain 